\title{
SPECIAL SECTION INTRODUCTION Community Impacts of Engaged Research, Teaching, and Practice
}

\author{
Peter Andrée, Nadine Changfoot, Charles Z. Levkoe
}

As the annals of the Michigan Journal of Community Service Learning can attest, engaged partnerships have become a powerful tool to enhance teaching and research on university and college campuses around the world. Community-campus engagement (CCE) is both an epistemological and methodological approach. It includes community-based research and participatory action research, community service learning as well as other forms of co-learning and knowledge mobilization. The Carnegie Foundation provides a strong overarching definition of community engagement as "the collaboration between institutions of higher education and their larger communities (local, regional/state, national, global) for the mutually beneficial exchange of knowledge and resources in a context of partnership and reciprocity."

While the above definition places CCE in the context of higher education, community-based organizations increasingly recognize the value of partnering with faculty, students, and campus staff to increase their capacity, broaden their reach, and accomplish their goals. However, there are inherent challenges involved in bringing typically small, and often underfunded, community-based organizations into partnership with large academic institutions, even when the principle of reciprocity is assumed. Acknowledging both the opportunities and challenges of partnership-based work, researchers and community-based practitioners have called for more community-oriented approaches that put the primary focus on generating meaningful benefits and impacts for community-based partners in CCE (Butcher, Bezzina, \& Moran, 2011; Cronley, Madden, \& Davis, 2015; Ward $\&$ Wolf-Wendel, 2000). This idea inspired a group of researchers and community-based practitioners from across Canada to create the Community First: Impacts of Community Engagement (CFICE) partnership research project.

Established in 2012 at Carleton University in Ottawa, and supporting activities across Canada, CFICE is a collaborative action research project that aims to better understand the many and diverse ways that communitycampus partnerships can be designed and implemented to maximize the value and impact for community-based organizations. The assumption underlying CFICE is that collaborative and mutually beneficial partnerships are an important part of building a healthier, more socially just and ecologically sustainable world. Over the first phase of CFICE, from 2012 to 2015, CCE demonstration projects were established across a range of the-

1. Defining Community Engagement, Swearer Center of Brown University, College and University Engagement Initiative. Retrieved from https://www.brown.edu/swearer/carnegie/about 
matic areas addressing pressing social and ecological issues including violence against women, community food security and food sovereignty (Andrée, Kepkiewicz, Levkoe, Brynne, \& Kneen, 2016; Kepkiewicz, Levkoe, \& Brynne, 2018; Kepkiewicz, Srivastava, Levkoe, Brynne, \& Kneen, 2017; Levkoe et al., 2016; Levkoe, BremWilson, \& Anderson, 2019; Levkoe, Erlich, \& Archibald, 2019; Nelson \& Dodd, 2016), poverty reduction (Erickson, Findlay, \& Christopherson-Cote, 2018; Pei, Feltham, Ford, \& Schwartz, 2015; Schwartz, Weaver, Pei, \& Miller, 2016; Zeng \& Honig, 2017), and community environmental sustainability (Martin \& Ballamingie, 2016; Nasca, Changfoot, \& Hill, 2018). In the second phase of CFICE, from 2015 to 2019, campus and community partners worked on cross-sector collaborations to further develop specific practices and approaches, including community-based CCE brokering (Levkoe, Schembri, \& Wilson, 2018; Levkoe \& Stack-Cutler, 2018; Levkoe \& Wilson, 2019), student pathways for community impact (Przednowek, Goemans, \& Wilson, 2018), and community-based organization access to research tools. ${ }^{2}$ The second phase of CFICE also resulted in a new national network and community-of-practice known as Community Campus Engage Canada (https://ccecanada.ca/), which is expected to carry the community first ethos forward on the national stage for years to come. All four of the co-editors of this special section of the Michigan Journal of Community Service Learning, including the three authors of this introduction, are academics deeply involved in CFICE. While we learn much in this collective project, this special section aspires to expand the conversation beyond CFICE partners on whether and how community first approaches to community-engaged research, teaching, and practice work and on how to maximize the community impact of CCE.

Working with the editors of Michigan Journal of Community Service Learning, we posted a broad call for research articles addressing community outcomes and impacts, the valuation of CCE, or advancement of the definition and measurement of community impacts. We received a strong response to the call and worked closely with a select group of authors to develop and refine their articles. (This process included double-blind peer reviews and independent oversight by the Michigan Joumal of Community Service Learning editors of all manuscripts by CFICE-related authors.) We are thrilled to present the fruits of our labor here, which include a wide range of contributions from academic-practitioners that build on foundations of social justice and ecological sustainability and demonstrate creativity, imagination, and experimentation. Many of these articles are rooted in embodied, experiential modes of making, thinking, learning, and doing; oriented toward current and future cultural and social conditions; and concerned with ways that these can be integrated into developing modes of research, teaching, policy, and practice.

Across the eleven articles presented in this special section, there are three main crosscutting themes. The first is the value and importance of examining community impact to inform why, how, and with whom CCE is undertaken. For example, this section's first article by Christopher Wegemer, Tafadzwa Tivaringe, Roudy Hildreth, Jennifer Pacheco, and Manuela Stewart Sifuentes focuses on the experiences of the Center for CommunityBased Learning and Engagement at the University of Colorado Boulder as that institution seeks to be more accountable to community first and collective impact principles through what these authors call "community-

2. See, for example, the community-based research toolkit at https://carleton.ca/cspsc/video-archive/community-based-research/. 
centered" work. Genevive Meredith, Amie Patchen, and Audrey Baker's article shares a similar story about a new Masters of Public Health program at Cornell University, created with broad stakeholder input that is adopting community-engaged learning to serve the overarching goals of strengthening the university's collective health impact while ensuring deeper, multidirectional learning among partners. Both pieces demonstrate the deep changes that are beginning to take place within some North American postsecondary institutions when they engage with discussions of whom CCE benefits and how their activities can bring greater benefit to the diverse communities that live and work within their sphere of influence.

For community-based participatory researchers, the question of community impact is not new (see, e.g., Janzen, Ochocka, \& Stobbe, 2016). This approach to research was developed, in part, to ensure that the needs and priorities of community partners drive the work (Strand, Marullo, Cutforth, Stoecker, \& Donohue, 2003). However, the articles in this collection demonstrate new ways of interrogating community impacts of community-based research. Emily Amon, Stephen Hill, Jim Blake, and Marie Gage amply demonstrate how a community-based research center that takes impact seriously can advance a social change agenda. Their article draws on the experience of a small nonprofit organization called the U-Links Centre for Community-Based Research in the rural community of Haliburton, Ontario. Amon and her co-authors argue for five factors that enable and affect positive community outcomes: relevance, rigor, reach, relationships, and resources. In their effort to advance how we make sense of the impacts of community-based research, Jennifer Bay and Kathryn Yankura Swacha introduce the post-structuralist theory of "meshworks." Their article demonstrates the importance of bringing to light relationships both inside and outside the frame of a CCE project that would not otherwise be addressed. It imparts important learnings about, for example, the use and limits of technology among food insecure clients. Bay and Swacha show how meshwork-informed methods allow for an expanded understanding of impact to include affective, embodied, and environmental experiences and also provide a research tool for consideration.

Whereas community-based research has paid some attention to the question of community impact over time, attention to community voices (see, e.g., Stoecker \& Tryon, 2009) and co-governance of projects (Goemans, Levkoe, Andrée, Changfoot, \& Christopherson-Cote, 2018) have been noted, and the issue of community impacts of international service learning remains underexplored. This collection offers two articles that examine the question of community impacts of international service learning. Luke Heidebrecht and Geraldine Balzer focus on projects in Mayan Indigenous communities in Guatemala and Nicaragua. As Global North and settler-researchers experimenting with decolonization as a theoretical framework, they offer their account of an encuentro (symposium) that brought together Indigenous hosts of North American students undertaking international service learning projects in their communities. The authors' discussion points to new ways to practice reciprocity in an international context of highly unequal power relations. Also focusing on international service learning, Anne Spear and Natasha Chapman's article seeks to measure the impact of such a project through impact assessment in $\mathrm{R}$ wanda. Their research finds that the installation of solar panels through an international service learning project based in Hong Kong produced a range of positive outcomes and impacts, especially in terms of empowering women in the community. However, some factors that may have shaped these positive impacts, such as the government's international development strategy or the role of local nongovernmental 
organizations in supporting the project, were beyond the scope of their community impact assessment. These findings point to the need for new methodologies to describe and measure community impact.

The second crosscutting theme found in many of the articles in this special section is the resistance to widely used tools for measuring CCE outcomes and impacts, combined with an effort to explore new impact measures, tools, and approaches that center community. Several articles argue that conventional impact tools are limited and narrowly construed and that there are good reasons to resist, challenge, and repurpose them or to look to other approaches and tools for a better fit with the challenge and opportunity of centering community impact. For example, David Peacock, Magdalene Goemans, Peter Andrée, Charles Levkoe, Nadine Changfoot, and Isabelle Kim push back on measures and models common to the not-for-profit sector that reify top-down impact reporting. They turn to Harvey's (1996) space-time theory and Bernstein's (1990) theory of recontextualized social practices as an entry for arguing that social theory should have a greater role in the impact conversation and the need to give more attention to the context-specific timescales of communities themselves. There is a caution against a one size fits all approach for outcome aspirations and understanding impact in community-specific projects. Connie Nelson and Mirella Stroink also challenge readers to think in new ways by encouraging evaluators to move beyond measurements of outcomes for specific beneficiaries of CCE (such as faculty, students, or community-based organizations) in favor of an approach grounded in complexity science that is more holistic. They argue that such an approach is better suited to the dynamic, multi-directional, and nonlinear dynamics of complex CCE systems. A complexity science-based evaluation would foreground context, examine interactions, and observe emergent outcomes to present a more fulsome picture of the impacts of CCE.

The third crosscutting theme across these articles is a clear call to center relationships between postsecondary institutions and community-based organizations based in the highly relational principles of meaningful reciprocity and partnership. Within CFICE, our research recognized the need to pay attention, first and foremost, to the relationships that take place in CCE, both individual and institutional (Andrée et al., 2014; Goemans et al., 2018). Articles in this special section show that being relational means being contextual and place based. Charles Levkoe and Lauren Kepkiewicz question the value of standardized outcome measures led by funders and academics. They point to the need for impact to be understood as contextual, relational, and process based. Presenting research from Phase I of CFICE's Community Food Security/Sovereignty hub, they further problematize the idea of impact by analyzing two emergent themes: the development of collaborative knowledge and actions and the development of networks of CCE communities of practice within social movement networks.

Recognition of CCE in tenure and promotion processes is an important aspect of strengthening postsecondary institutions' commitment for CCE. Nadine Changfoot, Peter Andrée, Charles Levkoe, Michelle Nilson, and Magdalene Goemans argue that although CCE is increasingly valued in tenure and promotion processes, the push to recognize the impact of CCE research and teaching as relational and collaborative with outputs attuned to community, in addition to traditional scholarly, peer-reviewed outputs, continues. They argue that tenure and promotion processes need to be better aligned with institutional commitments to CCE. While CCE should center community, the characteristics of these relationships and their impact benefit from further study During Mary Sweatman and Alan Warner's three-year study with three diverse community-based organizations 
(a long-term care facility, a farmers' market, and a leadership program), a model of community service learning emerged that embodied a shared domain of reciprocity, dialogue, and praxis and an iterative process that required ongoing trust and care for the partnerships.

As members of the editorial team for this special section of the Michigan Journal of Community Service Learning, we are pleased to offer these eleven new research articles and case studies to further the conversation on community impact and community first approaches to CCE. These articles do not answer all outstanding questions on how to study, measure, and discuss such impacts. However, collectively, these articles show that the question of community impact is important and that there are tools we can already start using to account for this impact. Furthermore, although simple measures and linear models of social change are probably not sufficient, intriguing new theoretical and methodological approaches are in development that center relationship building at the heart of CCE. Issues of funding, especially recognizing community partners contributions, are also ongoing. We hope you enjoy this special section. We look forward to reading future contributions to this conversation that these articles are sure to encourage. Thank you to the authors of these articles for their important insights, to the Michigan Journal of Community Service Learning editorial team for giving us this venue to explore these issues, and to the myriad CFICE partners that keep telling us that these questions are important if CCE is to walk its talk.

\section{References}

Andrée, P., Chapman, D., Hawkins, L., Kneen, C., Martin, W., Muehlberger, C., . . \& Stroink, M. (2014). Building effective relationships for community-engaged scholarship in Canadian food studies. Canadian Food Studies / La Revue Canadienne Des études Sur L'alimentation, 1(1), 27-53.

Andrée, P., Kepkiewicz, L., Levkoe, C., Brynne, A., \& Kneen, C. (2016). Learning, food, and sustainability in community-campus engagement: Teaching and research partnerships that strengthen the food sovereignty movement. In J. Sumner (Ed.), Learning, food, and sustainability: Sites for resistance and change (pp. 133153). New York, NY: Palgrave Macmillan.

Bernstein, B. (1990). Class, codes and control: Vol. 4. The structuring of pedagogic discourse. New York, NY: Routledge.

Butcher, J., Bezzina, M., \& Moran, W. (2011). Transformational partnerships: A new agenda for higher education. Innovative Higher Education, 36(1), 29-40.

Cronley, C., Madden, E., \& Davis, J. B. (2015). Making service-learning partnerships work: Listening and responding to community partners. Journal of Community Practice, 23(2), 274-289.

Erickson, L., Findlay, I., \& Christopherson-Cote, C. (2018). Rooting out poverty: People, passion, and place at Station 20 West. Engaged Scholar Journal: Community-Engaged Research, Teaching, and Learning, 4(2), 95-104.

Goemans, M., Levkoe, C. Z., Andrée, P., Changfoot, N., \& Christopherson-Cote, C. (2018). Learning to "walk the talk": Reflexive evaluation in community-first engaged research. Engaged Scholar Journal: CommunityEngaged Research, Teaching, and Learning, 4(2), 61-84. 
Harvey, D. (1996). Justice, nature and the geography of difference. Malden, MA: Blackwell Publishers.

Janzen, R., Ochocka, J., \& Stobbe, A. (2016). Towards a theory of change for community-based research projects. Engaged Scholar Journal: Community-Engaged Research, Teaching, and Learning, 2(2), 44-64.

Kepkiewicz, L., Levkoe, C. Z., \& Brynne, A. (2018). "Community first” for whom? Reflections on the possibilities and challenges of community-campus engagement from the Community Food Sovereignty Hub. Engaged Scholar Journal: Community-Engaged Research, Teaching, and Learning, 4(2), 43-60.

Kepkiewicz, L., Srivastava, R., Levkoe, C. Z., Brynne, A., \& Kneen, C. (2017). Community engaged action research and food sovereignty in Canada. In Peoples Knowledge Editorial Collective (Eds.), Everyday experts: How people's knowledge can transform the food system (pp. 292-307). Coventry, UK: Coventry University.

Levkoe, C. Z., Andrée, P., Bhatt, V., Brynne, A., Davison, K. M., Kneen, C., \& Nelson, E. (2016). Collaboration for transformation: Community-campus engagement for just and sustainable food systems. Journal of Higher Education Outreach and Engagement, 20(3), 23-61.

Levkoe, C. Z., Brem-Wilson, J., \& Anderson, C. R. (2019). People, power, change: Three pillars of a food sovereignty research praxis. The Journal of Peasant Studies, 46(7), 1389-1412.

Levkoe, C. Z., Erlich, S., \& Archibald, S. (2019). Campus food movements and community service-learning: Mobilizing partnerships throughout the Good Food Challenge in Canada. Engaged Scholar Journal: Community-Engaged Research, Teaching, and Learning, 5(1): 57-76.

Levkoe, C. Z., Schembri, V., \& Wilson, A. (2018). Community-academic peer review: Prospects for strengthening community-campus engagement and enriching scholarship. Engaged Scholar Journal: CommunityEngaged Research, Teaching, and Learning, 4(2), 1-20.

Levkoe, C. Z., \& Stack-Cutler, H. (2018). Brokering community-campus partnerships: An analytical framework. Gateways: International Journal of Community Research and Engagement, 11(1): 18-36.

Levkoe, C. Z., \& Wilson, A. (2019). Policy engagement as prefiguration: Experiments in food policy governance through the National Food Policy Dialogue in Canada. In P. Andrée, J. K.Clark,, C. Z. Levkoe, \& K. Lowitt (Eds.), Civil society and social movements in food system governance (pp. 101-123). New York, NY: Routledge.

Martin, G., \& Ballamingie, P. (2016). Critical research note-Faith missions and church redevelopment in Ottawa, Ontario. Canadian Journal of Urban Research, 25(1), 80-87.

Nasca, T. F., Changfoot, N., \& Hill, S. D. (2018). Participatory planning in a low-income neighbourhood in Ontario, Canada: building capacity and collaborative interactions for influence. Community Development Journal, 54(4), 622-642.

Nelson, E., \& Dodd, W. (2016). Collaborating for community food security: Emerging scholar participation in a community-university partnership. Action Research, 15(4), 402-423. doi:10.1177/147675031665604

Pei, N., Feltham, J., Ford, I., \& Schwartz, K. (2015). Best practices for implementing a living wage policy in Canada: Using community-campus partnerships to further the community's goal. Engaged Scholar Journal: Community-Engaged Research, Teaching, and Learning, 1(1), 87-106.

Przednowek, A., Goemans, M., \& Wilson, A. (2018). "I had a big revelation”: Student experiences in communityfirst community-campus engagement. Engaged Scholar Journal: Community-Engaged Research, Teaching, and Learning, 4(2), 21-42. 
Schwartz, K., Weaver, L., Pei, N., \& Miller, A. K. (2016). Community-campus partnerships, collective impact and poverty reduction. Community Development, 47(2), 167-180. doi:10.1080/155575330.215.1128955

Stoecker, R., \& Tryon, E. A. (2009). The unheard voices: Community organizations and service learning. Philadelphia, PA: Temple University Press.

Strand, K., Marullo, S., Cutforth, N., Stoecker, R., \& Donohue, P. (2003). Principles of best practice for community-based research. Michigan Journal of Community Service Learning, 9(3), 5-15.

Ward, K., \& Wolf-Wendel, L. (2000). Community-centered service learning: Moving from doing for to doing with. American Behavioral Scientist, 43(5), 767-780.

Zeng., Z., \& Honig, B. (2017). A study of living wage effects on employees' performance-related attitudes and behaviour. Canadian Journal of Administrative Sciences, 34(1), 19-32.

\section{Authors}

PETER ANDRÉE is Associate Professor in the Department of Political Science at Carleton University in Ottawa. He practices, and teaches, community-based participatory research methods. He served as Principal Investigator of the SSHRC-funded Community First: Impacts of Community Engagement (CFICE) partnership research project from 2014 to 2019.

NADINE CHANGFOOT is Associate Professor in Political Studies and Trent Centre for Aging and Society at Trent University, Trent University Teaching Fellow, and Senior Research Associate with Re•Vision: The Centre of Art and Social Justice. She engages in feminist, engaged arts-based research, partnering with environmental, disability, aging, health care, and Indigenous communities for influence and new possibilities.

CHARLESZ. LEVKOE is the Canada Research Chair in Sustainable Food Systems, the Director of the Sustainable Food Systems Lab and an Associate Professor in the Department of Health Sciences at Lakehead University in Ontario. His community engaged research uses a food systems lens to better understand the importance of, and connections between social justice, ecological regeneration, regional economies, and active democratic engagement. 